Article

\title{
Evaluation of a New Mexico Landrace and Two Commercial Chile (Capsicum annuum) Cultivars under Four Furrow Irrigation Schedules
}

\author{
Israel Joukhadar * and Stephanie Walker \\ Extension Plant Sciences, New Mexico State University, 945 College Dr., Las Cruces, NM 88003, USA; \\ swalker@nmsu.edu \\ * Correspondence: icalsoya@nmsu.edu; Tel.: +1-575-646-1715
}

Received: 8 December 2017; Accepted: 14 February 2018; Published: 24 February 2018

\begin{abstract}
Commercial and landrace chile (Capsicum annuum) cultivars are cultivated under furrow irrigation systems in Northern New Mexico. Yield and physiological differences between commercial and landrace chile cultivars under furrow irrigation systems have not been evaluated. In 2011 and 2012 two commercial chiles, 'Sandia' and 'NuMex Big Jim', with one landrace chile, 'Chimayo', were evaluated under four irrigation schedules, with irrigation once every 7, 9, 11, and 13-days. These four schedules represent possible water availability for farmers in Northern New Mexico. In 2011 there were inconsistent yield patterns; fresh red chile yield of 'Chimayo' at the seven-day interval was $90 \%$ more than at the nine-day interval. 'Sandia' had $138 \%$ better yields at the seven- than at the nine-day interval. 'Chimayo' fresh green chile yields at the nine-day interval were $47 \%$ better than the seven-day interval. 'NuMex Big Jim' fresh green yields were $40 \%$ greater at the seven-day interval than the 13-day interval. In 2012 no yield components were statistically different for cultivars across irrigation intervals. This data shows commercial green and landrace chile cultivars can be furrow irrigated as water becomes available on 7, 9, 11, or 13-day intervals with no yield effect.
\end{abstract}

Keywords: acequia; chile; commercial cultivars; ecosystem services; irrigation; landraces

\section{Introduction}

As the population of the world increases, so will the need for more efficient and sustainable food production. The United Nations Environment Program predicts agricultural water use is expected to rise by $19 \%$ by 2050 [1]; simultaneously, more regions (especially arid and semi-arid regions) will experience water shortages. Global water shortage analyses show that up to $76 \%$ of the world's population will be affected by water shortages over the next several decades [2].

The upper Rio Grande Valley in Northern New Mexico is defined as a semi-arid environment [3,4] and so is at high risk of water shortages for agricultural and domestic use in the present and future. Northern New Mexico derives $98.8 \%$ of its surface water from snowpack melt from the San Juan Mountain Range in Southern Colorado [5,6], but decreasing trends in snow depth and snow cover threaten water security in the Western United States [7]. Most farmers in Northern New Mexico depend on supplemental surface irrigation delivered through traditional acequia systems to fulfill crop water requirements because of low annual precipitation.

Acequias are ditch systems brought to the New World over 400 years ago [8] that divert water away from a river or stream to allow gravity-driven irrigation in the downstream floodplain between the acequia and river [9]. Acequia water levels directly depend on the amount of snowpack melting into rivers and streams [8]. As the snowpack declines and weather patterns change acequia water levels become unpredictable and scarce, posing a problem for farmers using the water to flood irrigate their crops [10]. A potential solution for this problem is thought to be to change all Northern New Mexico 
irrigation systems to more efficient water-conserving systems where water could be taken from the acequias and put into a holding tank or lined pond for use in a drip or sprinkler irrigation system. However, increasing efficiency with sprinklers and/or drip irrigation does not necessarily indicate better water conservation [11] or better conditions for the environment. This is the case in deep percolation environmental zones (highly permeable soils and small-sized basins with narrow floodplains, like some areas of Northern New Mexico) where water can readily percolate below the root zone and recharge aquifers [12]. When surface water is held in a furrow, ditch, or basin, aquifer recharge can occur [13]; the water is in one place long enough to seep below the root zone then into the aquifer. During the growing season between April and September surface water is removed from acequias and used to furrow irrigate fields in Northern New Mexico helping recharge aquifers. Aquifer recharge is only one of the ecosystem services furrow irrigation from the acequia ditches provides for the environment. Other ecosystem services provided by the use of acequias is seepage from the ditch channeling the water in between farms; besides recharging groundwater, this seepage also sustains riparian vegetation along the ditch [9]. Increasing irrigation efficiency of Northern New Mexico farms by changing all furrow irrigation to drip or sprinkler irrigation may reduce groundwater and aquifer recharge and riparian vegetation. It is important to evaluate how different cultivars of chile, a staple crop of Northern New Mexico, responds to variable furrow irrigation water availability.

New Mexico has a long history of growing chile dating back to the late 1500s. Two main types of chile are produced, red chile, which is a mature red fruit that is dried and ground to use as flakes or powder, and green chile, which is a green full-size physiologically-immature fruit sold fresh or packed as a frozen or canned product [14]. In Northern New Mexico many landrace varieties [15] are, and have been, historically grown on acequia irrigation systems. Landraces, such as 'Chimayo', 'Dixon', and 'Velarde', in Northern New Mexico were developed for more than 400 years through a process of seed-saving practiced by communities where seeds were passed down through generations [16]. Landraces are crops grown for a long time within a specific environment that have the ability to tolerate local stresses and have high yield sustainability when grown under low input agricultural systems [17]. They are well adapted to the environments in which they have been historically cultivated.

Generations of farmers in Northern New Mexico selected the best performing chile plants to save seed from each year bringing forth plants better adapted to the local climate [16]. Therefore, landrace chile grown in Northern New Mexico may have a better response to the local conditions than commercial cultivars bred for traits, such as increased yield, disease resistance, and improved quality, that are not location specific [18]. 'Chimayo', the landrace variety selected for this study, is known for its deep red color and unique flavors [16], and has been cultivated in Northern New Mexico for hundreds of years. 'Chimayo' has a very high market value and has been produced using furrow irrigation.

'Sandia' and 'NuMex Big Jim' are commercial varieties grown mostly in Southern New Mexico. 'Sandia' was originally developed to be harvested as a red chile [19] and 'NuMex Big Jim' was developed for green chile harvest [20]. Today, commercial green chile is cultivated on drip irrigation due to its higher market value and red chile is still furrow irrigated, but in Northern New Mexico the majority of famers still use furrow irrigation from an acequia system on both red and green chile. Cultivation of commercial red and green chile cultivars has increased in Northern New Mexican farms, yet the response of commercial and/or landrace varieties to different furrow irrigation schedules has not been quantified.

The primary objective of this research was to compare one landrace chile variety, Chimayo, and two commercial chile cultivars, NuMex Big Jim and Sandia, grown in the semi-arid environment of Northern New Mexico under four different furrow irrigation schedules. Commercial and landrace chile performance was evaluated based on yield components and physiological components. Yield components included fresh red fruit, fresh green fruit, dry red fruit, immature fruit, and diseased fruit. Physiological components included extractable color and pungency. 


\section{Materials and Methods}

\subsection{Description of the Study Area}

The experiment was conducted March-August in 2011 (Year 1) and 2012 (Year 2) at the New Mexico State University (NMSU) Sustainable Agriculture Science Center (lat. $36^{\circ} 5^{\prime} \mathrm{N}$; long. $106^{\circ} 3^{\prime} \mathrm{W}$; elevation $1733 \mathrm{~m}$ ) in Alcade, New Mexico. The site is within a semi-arid valley flood plain, with highly permeable soils. Fruitland sandy loam (coarse-loamy, mixed, calcareous, mesic Typic Torriorthents; [21]) was the dominate soil type in the experimental plots. The major crops grown in the area include alfalfa (Medicago sativa), fruit trees, various vegetables, and chile [22]. During the growing season in Year 1 (17 May-12 August 2011) and Year 2 (15 May-21 August 2012) there was no recorded precipitation (see Tables 1 and 2; [23]). The average maximum temperature during the growing season in Year 1 was $31.1^{\circ} \mathrm{C}$ and in Year 2 was $32.2^{\circ} \mathrm{C}$ (see Tables 1 and 2; [23]). The average minimum temperature during the growing season in Year 1 was $11.0^{\circ} \mathrm{C}$ and in Year 2 was $11.3^{\circ} \mathrm{C}$ (see Tables 1 and 2; [23]).

Table 1. Growing season (17 May-12 August 2011) weekly total precipitation and average maximum and minimum temperatures ${ }^{\mathrm{x}}, 2011$.

\begin{tabular}{cccc}
\hline Week & Maximum Temperature $\left({ }^{\circ} \mathbf{C}\right)$ & Minimum Temperature $\left({ }^{\circ} \mathbf{C}\right)$ & Precipitation $\mathbf{y}(\mathbf{c m})$ \\
\hline 1 & 20.8 & 3.4 & 0.0 \\
2 & 26.3 & 6.2 & 0.0 \\
3 & 31 & 9.6 & 0.0 \\
4 & 31.3 & 7.6 & 0.0 \\
5 & 31.1 & 9.7 & 0.0 \\
6 & 33.8 & 9.7 & 0.0 \\
7 & 32.9 & 11.6 & 0.0 \\
8 & 33.9 & 14.3 & 0.0 \\
9 & 32.7 & 14.2 & 0.0 \\
10 & 33.1 & 15.7 & 0.0 \\
11 & 30.9 & 14.8 & 0.0 \\
12 & 32.5 & 13.2 & 0.0 \\
13 & 34.2 & 13 & 0.0 \\
Season Average & 31.1 & 11.0 & 0.0 \\
\hline
\end{tabular}

x Precipitation and temperature collected from Natural Resources Conservation Service (2011); station \#2172;

y Total precipitation during week; ${ }^{\mathrm{z}}$ Total precipitation during season.

Table 2. Growing season (15 May-21 August 2012) weekly total precipitation and average maximum and minimum temperatures ${ }^{\mathrm{x}}, 2012$.

\begin{tabular}{cccc}
\hline Week & Maximum Temperature $\left({ }^{\circ} \mathbf{C}\right)$ & Minimum Temperature $\left({ }^{\circ} \mathbf{C}\right)$ & Precipitation ${ }^{\mathbf{y}}(\mathbf{c m})$ \\
\hline 1 & 27.9 & 5.9 & 0.0 \\
2 & 28.5 & 5.9 & 0.0 \\
3 & 30.8 & 6.3 & 0.0 \\
4 & 32.1 & 8.1 & 0.0 \\
5 & 32.8 & 10.1 & 0.0 \\
6 & 35.3 & 11.3 & 0.0 \\
7 & 35.7 & 14.0 & 0.0 \\
8 & 30.4 & 13.8 & 0.0 \\
9 & 32.4 & 13.3 & 0.0 \\
10 & 33.7 & 12.8 & 0.0 \\
11 & 33.4 & 14.5 & 0.0 \\
12 & 32.8 & 14.9 & 0.0 \\
13 & 33.3 & 14.4 & 0.0 \\
14 & 31.1 & 12.8 & 0.0 \\
Season Average & 32.2 & 11.3 & $0.0^{\mathrm{z}}$ \\
\hline
\end{tabular}

\footnotetext{
x Precipitation and temperature collected from Natural Resources Conservation Service (2012); station \#2172;
}

y Total precipitation during week; ${ }^{\mathrm{z}}$ Total precipitation during season. 


\subsection{Experimental Design and Treatments}

The experiment was conducted using a split plot design with three replications where irrigation levels were allocated to main plots and cultivars to sub-plots (Figure 1). Rows were $1 \mathrm{~m}$ apart and within-row plant spacing was $30 \mathrm{~cm}$. Each sub-plot was three rows of a randomized selection of one cultivar (Chimayo, NuMex Big Jim, or Sandia) in $30 \mathrm{~m}^{2}(3.0 \mathrm{~m} \times 10 \mathrm{~m})$ plot. Each main plot was a randomized selection of one irrigation interval (13-day interval, 11-day interval, nine-day interval, and seven-day interval), $120 \mathrm{~m}^{2}(3.0 \mathrm{~m} \times 40 \mathrm{~m})$.

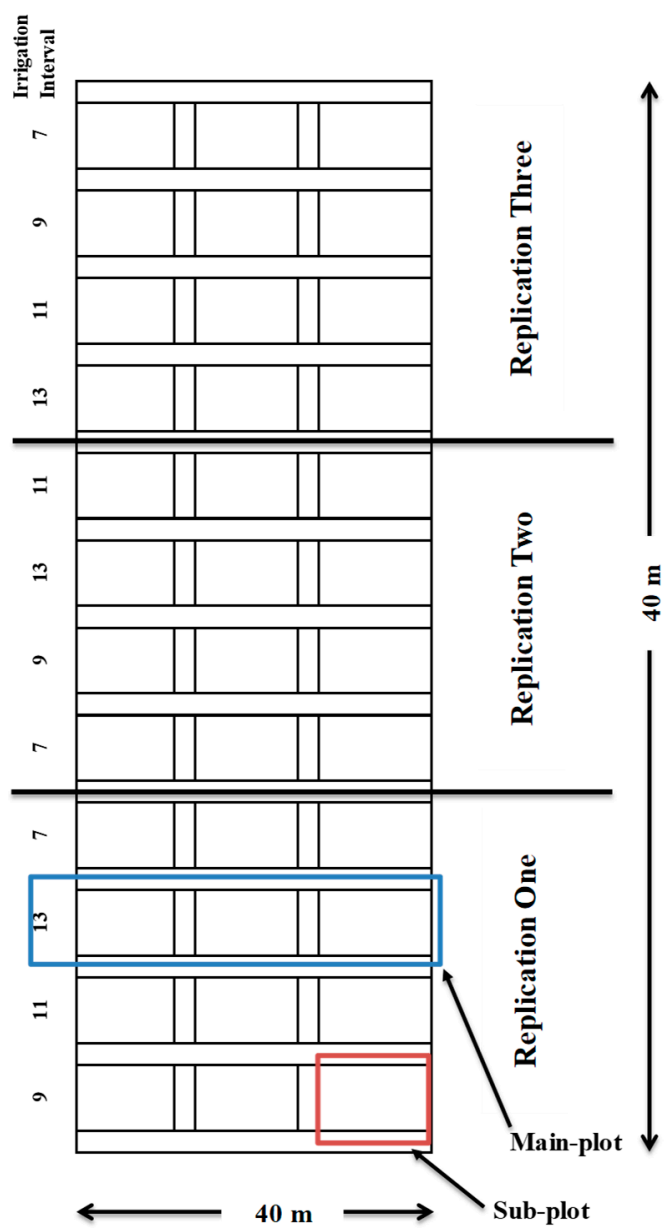

Figure 1. Split-plot experimental design with main plots and sub-plots, 2011 and 2012.

\subsection{Seedling Establishment and Transplanting}

'Chimayo', 'Sandia', and 'NuMex Big Jim' seeds were sown on 14 March 2011 (Year 1) and 19 March 2012 (Year 2) in greenhouse at NMSU's Fabian Garcia Science Center in Las Cruces, NM, USA, into $3.9 \times 2.7 \times 5.5 \mathrm{~cm}$ compartments of 12-celled planting containers (Hummert International, Earth City, MO, USA, cat\# 11-0450) containing a Redi-Earth plug and potting mix ${ }^{\circledR}$ made by Sungro (Agawam, MA, USA). Miracle grow liquid fertilizer ${ }^{\circledR}$ (The Scotts Miracle-Gro Company, Marysville, $\mathrm{OH}, \mathrm{USA}$ ) was applied two times at manufacturer rates twice after emergence. During seedling establishment in the greenhouse plants were watered twice a day with a hose until saturated. Seedlings were transported to Alcalde, NM, USA, and placed outside to harden-off for two weeks in full sun. Seedlings were transplanted 34 days after emergence in Year 1 and 32 days after emergence in Year 2 and irrigated immediately after transplanting. In Year 2 cutworms (Agrotis segetum) damaged more than 100 plants that had to be replaced by new transplants. Fertilization during both years consisted of nitrogen (Helena Chemical Company, Albuquerque, NM, USA) at $224.2 \mathrm{~kg} \cdot \mathrm{ha}^{-1}$ (200 lb/acre) and 
phosphorous at $112.1 \mathrm{~kg} \cdot \mathrm{ha}^{-1}(100 \mathrm{lb} / \mathrm{acre})$ that was side-dressed by hand twice in both seasons, 1 June 2011 and 2012 at the beginning and, 13 July 2011 and 2012 at the middle of the season at the recommended rate [24]. The plots were hand-weeded 24 times during the growing seasons to minimize weeds.

\subsection{Crop Data}

The total crop yield and physiological components per plot were recorded from two meters from the middle $\left(2.0 \mathrm{~m}^{2}\right)$ row of each sub-plot. The plants were harvested completely and one randomly-selected plant was cut at the base of the stem for dry vegetative weight. Plants were harvested 88 days after transplanting (DAT) in Year 1 and 98 DAT in Year 2. The fresh yield was sorted into diseased (fruit with fungal, viral, and physical damage more than $30 \%$ ), immature, red, and green categories and fresh weights were obtained. Fresh red fruit from 'Chimayo' and 'Sandia' plots were weighed, dried for $72 \mathrm{~h}$ in a drier at $55^{\circ} \mathrm{C}$, then weighed again for the dry weight; then ten fruit were randomly selected from the dry red fruit and ground (Thomas-Wiley Mini-Mill Cutting Mill, Thomas Scientific, Swedesboro, NJ, USA, cat\# 3383L40; sieve \#40). Ten green 'NuMex Big Jim' fruit were dried at $55^{\circ} \mathrm{C}$ for $72 \mathrm{~h}$ and then ground (Thomas-Wiley Mini-Mill Cutting Mill, Thomas Scientific, Swedesboro, NJ, USA, cat\# 3383L40; sieve \#40).

The ground red fruit from 'Chimayo' and 'Sandia' were measured for extractable pigment using the American Spice Trade Association procedure and protocol [25]. The red ground fruit of 'Sandia,' 'Chimayo,' and green ground fruit of 'NuMex Big Jim' were analyzed for their heat level using the method described by Collins et al. [26] to extract, separate, and quantify the capsaicinoids using high-performance liquid chromatography (HPLC).

\subsection{Flood Irrigation System Installation}

A $20 \mathrm{~cm}$ diameter polyethylene pipe (poly-pipe) (Baron Irrigation Supply, Anthony, TX, USA) used for furrow irrigation was installed at the main valve according to Enciso and Peries [27] instructions. An earthen mound $0.9 \mathrm{~m}$ in height and $1.2 \mathrm{~m}$ wide was placed $3.0 \mathrm{~m}$ from the last furrow in the field. Poly-pipe was placed over this mound to gravity stop the water and to maintain overall pipe pressure. For every furrow, a $7.6 \mathrm{~cm}$ plastic flood gate was installed.

\subsection{Irrigation Schedule Development and Total Water Applied}

Irrigation intervals of 7,9,11, and 13 days were selected as potential intervals water could be available in the acequia ditches for use. The Hargreaves-Samani [28] equation was used to create irrigation amounts for each interval. The Hargreaves-Samani equation requires less climatological data to develop an irrigation schedule making it more suitable for our purposes. According to the standard guidelines chile requires $75 \mathrm{~cm} /$ hectare of water per season for optimal growing conditions [24,29]. The total water applied per hectare to each irrigation interval is as follows:

In Year 1: the seven-day interval received $71 \mathrm{~cm}$; the nine-day interval received $64 \mathrm{~cm}$; the 11-day interval received $59 \mathrm{~cm}$; the 13-day interval received $56 \mathrm{~cm}$. In Year 2: the seven-day interval received $75 \mathrm{~cm}$; the nine-day interval received $68 \mathrm{~cm}$; the 11-day interval received $63 \mathrm{~cm}$; the 13-day interval received $59 \mathrm{~cm}$. To measure each irrigation a $5.0 \mathrm{~cm}$ programmable paddle wheel flow meter with totalizers (Midwest Instruments and Controls, Rice Lake, WI, USA) was installed at the main valve, and was calibrated in accordance with the manufacturer's specifications to measure water exiting the main valve in gallons per minute (gpm). Circular flumes were built and used to measure and calibrate water flow from each flood gate [30]. The main valve was turned on at $40 \mathrm{gpm}$ as read by the paddle wheel flow meter for ten minutes until the poly-pipe was fully expanded with water, then gates were opened to a calibrated measurement. Gates were closed once the flow meter recorded the volume of water necessary for each irrigation event. 


\subsection{Statistical Analysis}

The parameters measured in this experiment were designed to evaluate effects of irrigation interval on total chile yield and fruit physiological components. Analysis was conducted on Year 1 and Year 2 data separately due to differences between each year. The differences between the years were temperature, length of growing time and, in Year 2, there was cutworm damage to over 50 plants right after transplanting. Experimental data were subjected to statistical analysis using the Statistical Analysis System (SAS) Version 9.3 (SAS Institute Inc., Cary, NC, USA) statistical software [31]. Fresh red yield, dry red yield, fresh green yield, immature yield, and diseased yield of chile, and chile extractable color and pungency data were analyzed using ANOVA $(p \leq 0.05)$. If statistically significant differences were found between means they were separated using a least significant difference test at $p \leq 0.05$.

\section{Results}

\subsection{Yield Components}

In Year 1 (Table 3), statistical differences were found in fresh red, fresh green, and dry red yield. Fresh red yield of 'Chimayo' at the seven-day interval was 90\% more than the fresh red yield of 'Chimayo' at the nine-day interval. Fresh red yield of 'Sandia' at the seven-day interval was $138 \%$ greater than the fresh red yield of 'Sandia' at the nine-day interval, yet 'Sandia' at the 13-day interval was statistically the same as the seven-day interval. Dry red yield of 'Chimayo' showed some differences, but they were not statistically significant. Dry red yield of 'Sandia' at the 11-day interval was four times greater than the dry red yield of 'Sandia' at the nine-day interval. 'Chimayo', the landrace variety in 2011, had better fresh red yield at the seven-day interval, while 'Sandia' the commercial cultivar showed no predictable preference for irrigation interval because, in fresh red yield, both the 7- and 13-day intervals had similar yields. 'Sandia' dry red yield was also the same for 7-, 11-, and 13-day intervals and dry red yields for 'Chimayo' were also statistically similar. The red dry and fresh yields of 'Chimayo' and 'Sandia' highlighted that reducing irrigation intervals did not affect yield in a predictable pattern. The statistical differences observed in Year 1 were not replicated in Year 2 (Table 4). In Year 2 no statistical differences were found in either fresh red or dry red yield; therefore, in a furrow irrigation system in Northern New Mexico where farmers are growing 'Chimayo' or 'Sandia' for fresh red or dry red yield, they can produce similar yields even if the water is not available every seven days. Diseased yield did not exhibit any statistical differences in Year 1 or Year 2, and the cultivars had the same percentage of diseased fruit at all irrigation intervals.

Fresh green yield for 'Chimayo' showed statistical differences; 'Chimayo' at the nine-day interval had $47 \%$ more yield than at the 13-day irrigation interval (Table 3). Fresh green yield of 'Sandia' at the seven-day interval was $102 \%$ greater than at the 11-day interval. Fresh green yield of 'NuMex Big Jim' at the seven-day interval was $40 \%$ more than at the 13-day interval. Again, the inconsistent yield pattern emphasizes using a seven-day interval did not ensure higher fresh green yields for each cultivar. This is supported further by Year 2 results (Table 4) where no statistical differences were observed within cultivars across irrigation intervals. Thus, farmers in Northern New Mexico that use furrow irrigation can irrigate as water is available up to at least a two-week interval and expect that the fresh green yield of 'Sandia', 'NuMex Big Jim', and/or 'Chimayo' will have minimal yield reductions. This is in agreement with Diaz-Perez et al. [32] who reported that irrigating peppers with less water than the recommended amounts might not affect chile yield. Longer irrigation intervals may not affect chile yield because once the canopy is fully established they are less sensitive to longer periods without water [33]. 
Table 3. Main effects and interactions of three cultivars and four irrigation intervals on yield components, 2011.

\begin{tabular}{|c|c|c|c|c|c|}
\hline \multirow[b]{2}{*}{ Cultivar } & \multirow[b]{2}{*}{ Irrigation Interval } & \multicolumn{4}{|c|}{ Harvest Response Variables ${ }^{\mathrm{z}}$} \\
\hline & & Fresh Red & Fresh Green & Dry Red & Diseased \\
\hline Chimayo & 7 & $4.0 \mathrm{a}^{\mathrm{y}}$ & $5.2 \mathrm{ab}$ & $0.8 \mathrm{a}$ & 0.1 \\
\hline Chimayo & 9 & $2.1 \mathrm{~b}$ & $6.3 \mathrm{a}$ & $0.4 \mathrm{ab}$ & 0.1 \\
\hline Chimayo & 11 & $3.3 \mathrm{ab}$ & $4.8 \mathrm{~b}$ & $0.7 \mathrm{a}$ & 0.4 \\
\hline Chimayo & 13 & $2.5 \mathrm{~b}$ & $4.3 \mathrm{c}$ & $0.5 \mathrm{ab}$ & 0.2 \\
\hline Sandia & 7 & $1.9 \mathrm{a}$ & $8.9 \mathrm{a}$ & $0.4 \mathrm{ab}$ & 0.1 \\
\hline Sandia & 9 & $0.8 \mathrm{~b}$ & $7.9 \mathrm{ab}$ & $0.1 \mathrm{~b}$ & 0.3 \\
\hline Sandia & 11 & $1.4 \mathrm{ab}$ & $4.4 \mathrm{~b}$ & $0.5 \mathrm{a}$ & 0.4 \\
\hline Sandia & 13 & $1.7 \mathrm{a}$ & $5.9 \mathrm{ab}$ & $0.4 \mathrm{ab}$ & 0.1 \\
\hline Big Jim & 7 & $-u$ & $14.1 \mathrm{a}$ & - & 0.6 \\
\hline Big Jim & 9 & - & $11.2 \mathrm{ab}$ & - & 0.9 \\
\hline Big Jim & 11 & - & $13.8 \mathrm{a}$ & - & 0.6 \\
\hline \multirow[t]{2}{*}{ Big Jim } & 13 & - & $10.1 \mathrm{~b}$ & - & 1.0 \\
\hline & & \multicolumn{4}{|c|}{ Significance $(p \leq 0.05)$} \\
\hline \multicolumn{2}{|c|}{ Irrigation Interval $^{\mathrm{v}}$} & 0.0040 & 0.0087 & 0.0372 & NS \\
\hline \multicolumn{2}{|c|}{ Cultivar ${ }^{\mathrm{w}}$} & $<0.0001$ & $<0.0001$ & $<0.0001$ & $<0.0001$ \\
\hline \multicolumn{2}{|c|}{ Irrigation Interval $\times$ Cultivar $x$} & $\mathrm{NS}^{\mathrm{t}}$ & NS & NS & NS \\
\hline
\end{tabular}

${ }^{\mathrm{z}}$ Mean chile yields harvested kg per $2 \mathrm{~m}^{2}$ plots; reported in ton ha ${ }^{-1}$. ${ }^{\mathrm{y}}$ Any two means within a column followed by the same letters are not significantly different (least significant difference) at $p \leq 0.05$; ${ }^{\mathrm{x}}$ Interaction between irrigation interval $x$ cultivar, if not significantly different, then main effects cultivar and irrigation interval tested at $p \leq 0.05$; $^{\mathrm{w}}$ Main effect, cultivar, significantly different at $p \leq 0.05$; $^{\mathrm{v}}$ Main effect, irrigation interval, significantly different at $p \leq 0.05{ }^{\mathrm{u}} \mathrm{Big}$ Jim fruit, not harvested at red physiologically mature stage; ${ }^{\mathrm{t}}$ Not significant at $p \leq 0.05$. Three replications per treatment.

Table 4. Main effects and interactions of three cultivars and four irrigation intervals on yield components, 2012.

\begin{tabular}{|c|c|c|c|c|c|}
\hline \multirow[b]{2}{*}{ Cultivar } & \multirow[b]{2}{*}{ Irrigation Interval } & \multicolumn{4}{|c|}{ Harvest Response Variables ${ }^{z}$} \\
\hline & & Fresh Red & Fresh Green & Dry Red & Diseased \\
\hline Chimayo & 7 & $1.3^{z}$ & 2.6 & 0.2 & 0.0 \\
\hline Chimayo & 9 & 1.5 & 2.6 & 0.4 & 0.1 \\
\hline Chimayo & 11 & 1.4 & 2.1 & 0.3 & 0.0 \\
\hline Chimayo & 13 & 1.1 & 3.4 & 0.2 & 0.1 \\
\hline Sandia & 7 & 1.6 & 4.0 & 0.3 & 0.0 \\
\hline Sandia & 9 & 1.7 & 3.4 & 0.2 & 0.0 \\
\hline Sandia & 11 & 0.8 & 3.2 & 0.2 & 0.1 \\
\hline Sandia & 13 & 0.9 & 3.8 & 0.1 & 0.0 \\
\hline Big Jim & 7 & $-\mathrm{v}$ & 8.7 & - & 0.0 \\
\hline Big Jim & 9 & - & 4.7 & - & 0.1 \\
\hline Big Jim & 11 & - & 5.3 & - & 0.1 \\
\hline \multirow[t]{2}{*}{ Big Jim } & 13 & - & 4.3 & - & 0.0 \\
\hline & & \multicolumn{4}{|c|}{ Significance $(p \leq 0.05)$} \\
\hline \multicolumn{2}{|c|}{ Irrigation Interval w } & NS $\mathrm{u}$ & NS & NS & NS \\
\hline \multicolumn{2}{|c|}{ Cultivar ${ }^{x}$} & $<0.0001$ & 0.0049 & $<0.0001$ & NS \\
\hline \multicolumn{2}{|c|}{ Irrigation Interval $\times$ Cultivar $\mathrm{y}$} & NS & NS & NS & NS \\
\hline
\end{tabular}

${ }^{\mathrm{z}}$ Mean chile yields harvested $\mathrm{kg}$ per $2 \mathrm{~m}^{2}$ plots; reported in ton ha ${ }^{-1}$. Any two means within a column followed by the same letters are not significantly different (least significant difference) at $p \leq 0.05$; ${ }^{y}$ Interaction between irrigation interval $x$ cultivar, if not significantly different, then main effects cultivar and irrigation interval tested at $p \leq 0.05$; ${ }^{\mathrm{x}}$ Main effect, cultivar, significantly different at $p \leq 0.05 ;{ }^{\mathrm{w}}$ Main effect, irrigation interval, significantly different at $p \leq 0.05{ }^{\mathrm{v}}$ Big Jim fruit, not harvested at red physiologically mature stage; ${ }^{\mathrm{u}}$ Not significant at $p \leq 0.05$. Three replications per treatment. 


\subsection{Physiological Components}

In Year 1 (Table 5), only two statistically significant differences were observed. 'Chimayo' at a nine-day interval had 38\% higher extractable color than at the 11-day interval. 'Sandia' at the nine-day interval was over 1.5X more pungent than at the seven-day interval. In Year 2 (Table 6), 'Sandia' at the seven-day irrigation interval was 95\% more pungent than at the nine-day irrigation interval, and 'NuMex Big Jim' at the 11-day interval was 122\% more pungent than at the 13-day interval. Lack of a noticeable pattern in pungency was to be expected due to the instability of pungency from season to season within each variety and the varied response of pungency to environmental conditions [18,34]. In other studies, a reduction in irrigation water led to increases in pungency [35]. Our study did not support a reduction of irrigation water leading to higher pungency, but it did show that 'Chimayo' had more consistent pungency levels across irrigation intervals in Year 1 and Year 2 because pungency levels were all non-significant across all irrigation intervals. Extractable color differences were only seen in Year 1 and in one cultivar; therefore, this study provides evidence that extractable color was not negatively affected by different furrow irrigation schedules in Northern New Mexico.

Table 5. Main effects and interactions of three cultivars and four irrigation intervals on physiological fruit characteristics, 2011.

\begin{tabular}{|c|c|c|c|}
\hline \multirow[b]{2}{*}{ Cultivar } & \multirow[b]{2}{*}{ Irrigation Interval } & \multicolumn{2}{|c|}{ Physiological Variables } \\
\hline & & Pungency ${ }^{\mathrm{y}}$ (Scoville Heat Units) & Extractable Red Color ${ }^{x}$ (ASTA Units) \\
\hline Chimayo & 7 & 6228.2 & $134.1 \mathrm{ab}$ \\
\hline Chimayo & 9 & 4771.8 & $150.7 \mathrm{a}$ \\
\hline Chimayo & 11 & 6833.2 & $109.2 \mathrm{~b}$ \\
\hline Chimayo & 13 & 5499.3 & $136.5 \mathrm{ab}$ \\
\hline Sandia & 7 & $5362.3 \mathrm{~b}^{\mathrm{z}}$ & 106.4 \\
\hline Sandia & 9 & $14,927.1 \mathrm{a}$ & 101.2 \\
\hline Sandia & 11 & $9312.1 \mathrm{ab}$ & 113.4 \\
\hline Sandia & 13 & $10,605.4 \mathrm{ab}$ & 107.7 \\
\hline Big Jim & 7 & 5860.9 & $-w$ \\
\hline Big Jim & 9 & $13,292.9$ & - \\
\hline Big Jim & 11 & $10,522.3$ & - \\
\hline \multirow[t]{2}{*}{ Big Jim } & 13 & 6233.4 & - \\
\hline & & \multicolumn{2}{|c|}{ Significance $(p \leq 0.05)$} \\
\hline \multirow{2}{*}{\multicolumn{2}{|c|}{ Irrigation Interval $^{\mathrm{t}}$}} & 0.0390 & $\mathrm{NS}^{\mathrm{s}}$ \\
\hline & & 0.0252 & $<0.0001$ \\
\hline \multicolumn{2}{|c|}{ Irrigation Interval $\times$ Cultivar ${ }^{\mathrm{v}}$} & NS & NS \\
\hline \multicolumn{4}{|c|}{$\begin{array}{l}\text { z Mean value, any two means within a column followed by the same letters are not significantly different } \\
\text { (least significant difference) at } p \leq 0.05 ; \mathrm{y} \text { Samples collected from } 2-\mathrm{m}^{2} \text {; ten randomly selected fruit; }{ }^{\mathrm{x}} \text { Samples } \\
\text { collected from } 2-\mathrm{m}^{2} \text {; ten randomly selected fruit; }{ }^{\mathrm{w}} \text { Big Jim fruit, not harvested at red physiologically mature stage; } \\
\mathrm{v} \text { Interaction between irrigation interval } \mathrm{x} \text { cultivar, if not significantly different, then main effects cultivar and } \\
\text { irrigation interval tested at } p \leq 0.05{ }^{\mathrm{u}} \text { Main effect, cultivar, significantly different at } p \leq 0.05 \text {; }{ }^{\mathrm{t}} \text { Main effect, irrigation } \\
\text { interval, significantly different at } p \leq 0.05{ }^{\mathrm{s}} \text { Not significant at } p \leq 0.05 \text {. Three replications per treatment. }\end{array}$} \\
\hline \multicolumn{4}{|c|}{$\begin{array}{l}\text { Table 6. Main effects and interactions of three cultivars and four irrigation intervals on physiological } \\
\text { fruit characteristics, } 2012 \text {. }\end{array}$} \\
\hline & & \multicolumn{2}{|c|}{$\begin{array}{l}\text { Physiological Variables } \\
\end{array}$} \\
\hline Cultivar & Irrigation Interval & Pungency ${ }^{\mathrm{y}}$ (Scoville Heat Units) & Extractable Red Color $^{x}$ (ASTA Units) \\
\hline Chimayo & 7 & $11,908.1$ & 125.5 \\
\hline Chimayo & 9 & $11,796.5$ & 113.7 \\
\hline Chimayo & 11 & 9281.0 & 135.1 \\
\hline Chimayo & 13 & $13,734.2$ & 107.6 \\
\hline
\end{tabular}


Table 6. Cont.

\begin{tabular}{|c|c|c|c|}
\hline \multirow[b]{2}{*}{ Cultivar } & \multirow[b]{2}{*}{ Irrigation Interval } & \multicolumn{2}{|c|}{ Physiological Variables } \\
\hline & & Pungency ${ }^{\mathrm{y}}$ (Scoville Heat Units) & Extractable Red Color ${ }^{x}$ (ASTA Units) \\
\hline Sandia & 7 & $14,834.5 \mathrm{a}^{\mathrm{z}}$ & 122.6 \\
\hline Sandia & 9 & $7588.6 \mathrm{~b}$ & 114.6 \\
\hline Sandia & 11 & $10,111.3 \mathrm{ab}$ & 121.9 \\
\hline Sandia & 13 & $12,969.1 \mathrm{ab}$ & 118.2 \\
\hline Big Jim & 7 & $6752.3 \mathrm{ab}$ & $-w$ \\
\hline Big Jim & 9 & $7821.6 \mathrm{ab}$ & - \\
\hline Big Jim & 11 & $9523.2 \mathrm{a}$ & - \\
\hline \multirow[t]{2}{*}{ Big Jim } & 13 & $4281.2 \mathrm{~b}$ & - \\
\hline & & \multicolumn{2}{|c|}{ Significance $(p \leq 0.05)$} \\
\hline \multicolumn{2}{|c|}{ Irrigation Interval $^{\mathrm{t}}$} & $\mathrm{NS}^{\mathrm{s}}$ & NS \\
\hline \multicolumn{2}{|c|}{ Cultivar ${ }^{\mathrm{u}}$} & 0.0026 & NS \\
\hline \multicolumn{2}{|c|}{ Irrigation Interval $x$ Cultivar ${ }^{\mathrm{v}}$} & NS & NS \\
\hline $\begin{array}{l}\mathrm{z} \text { Mean } \\
\text { (least sig } \\
\text { collected } \\
\mathrm{v} \text { Interact } \\
\text { irrigation } \\
\text { interval, }\end{array}$ & $\begin{array}{l}\text { alue, any two means } \\
\text { ificant difference) at } \\
\text { rom } 2-\mathrm{m}^{2} \text {; ten random } \\
\text { lon between irrigatior } \\
\text { interval tested at } p \leq 0 \\
\text { ignificantly different a }\end{array}$ & $\begin{array}{l}\text { vithin a column followed by the san } \\
\leq 0.05 \text {; }^{\text {y }} \text { Samples collected from } 2-\mathrm{m}^{2} \\
\text { selected fruit; }{ }^{\text {w }} \text { Big Jim fruit, not harv } \\
\text { nterval x cultivar, if not significantly } \\
\text {; u Main effect, cultivar, significantly di } \leq 0.05 \text {; }^{\mathrm{s}} \text { Not significant at } p \leq 0.05 \text {. T }\end{array}$ & $\begin{array}{l}\text { letters are not significantly different } \\
\text { en randomly selected fruit; }{ }^{x} \text { Samples } \\
\text { ted at red physiologically mature stage; } \\
\text { fferent, then main effects cultivar and } \\
\text { erent at } p \leq 0.05{ }^{t} \text { Main effect, irrigation } \\
\text { ee replications per treatment. }\end{array}$ \\
\hline
\end{tabular}

\section{Discussion}

This experiment was harvested at one time, which may have had an impact on the results because each cultivar may not have been at optimal maturity for harvest. 'Chimayo' is mostly grown for harvest at a mature red stage, while 'Sandia' can be harvested at the mature red fruit stage or, like, 'NuMex Big Jim', harvested when green fruit are full-sized, but physiologically immature. Harvesting the different varieties all at once may have impacted the yields and physiological components. The fresh red yields of 'Chimayo' and 'Sandia' may have increased if the harvest had been delayed, while the fresh green yields of 'NuMex Big Jim' and 'Sandia' may have increased if harvest had been a week earlier. Additionally, Year 2 yields were generally lower due to the cutworm damage that occurred after transplanting. The severely damaged plants had to be removed and replaced by new transplants, which had a negative impact on overall yield. The lower yields of Year 2 could explain the lack of detected statistical differences.

'Chimayo', 'Sandia', and 'NuMex Big Jim' performed about the same under the different furrow irrigation intervals. There were some significant differences in Year 1 yield components, but they were not observed again in Year 2. Furrow irrigation from traditional acequia systems used by farmers for hundreds of years in Northern New Mexico can supply the water necessary to sustain yields and quality of both commercial and landrace cultivars even if the irrigation water is not readily available for weekly irrigation events. As stated in the introduction, unpredictable water availability in the Northern New Mexico acequia system has farmers looking for solutions on how to consistently irrigate their crops. More efficient irrigation, such as drip or sprinkler irrigation could be seen as the solution, yet we must account for the ecological services provided by furrow irrigation from acequia ditches. Ecological services, such as recharge of aquifers and sustaining riparian vegetation along ditches, contribute to long-term environmental sustainability. This research shows continued use of the furrow irrigation system from acequia ditches will maintain yield and physiological characteristics of both commercial and landrace varieties even if the water is not available on a weekly basis.

Author Contributions: All authors conceived and designed the experiments. Israel Joukhadar performed the experiments, collected and analyzed the data, and wrote the manuscript with Stephanie Walker.

Conflicts of Interest: The authors declare no conflict of interest. 


\section{References}

1. United Nations Environment Program. Global Environmental Outlook (GEO-4). Environment for Development Home Page. 2007. Available online: http:/ / www.unep.org/geo/geo4.asp (accessed on 23 August 2017).

2. Wallace, J.; Gregory, P. Water resources and their use in food production. Agric. Ecosyst. Environ. 2002, 82, 105-119. [CrossRef]

3. Lugo, A.; Brown, S.; Dodson, R.; Smith, T.; Shugart, H. The Holdridge life zone of the conterminous United States in relation to ecosystem mapping. J. Biogeogr. 1999, 26, 1025-1038. [CrossRef]

4. National Climatic Data Center. NOAA's 1981-2010 Climate Normals. Available online: http:/ /www.ncdc. noaa.gov/oa/climate/normals/usnormals.html (accessed on 23 August 2017).

5. Stephens, D.; Lewis, A. Jemez and Sangre Regional Water Plan; Daniel Stephens and Associates: Albuquerque, NM, USA, 2003.

6. Elias, E.; Rango, A.; Steele, C.; Mejia, J.; Smith, R. Assessing climate change impacts on water availability of snowmelt-dominated basins of the Upper Rio Grande basin. J. Hydrol. Reg. Stud. 2015, 3, 525-546. [CrossRef]

7. Dyer, J.; Mote, T. Spatial Variability and trends observed snow depth over North America. Geophys. Res. Lett. 2006, 33, L16503. [CrossRef]

8. Fernald, A.; Tidwell, V.; Rivera, J.; Rodríguez, S.; Guldan, S.; Steele, C.; Ochoa, C.; Hurd, B.; Ortiz, M.; Boykin, K.; et al. Modeling sustainability of water, environment, livelihood, and culture in traditional irrigation communities and their linked watersheds. Sustainability 2012, 4, 2998-3022. [CrossRef]

9. Fernald, A.; Baker, T.; Guldan, S. Hydrologic, riparian, and agroecosystem functions of traditional acequia irrigation systems. J. Sustain. Agric. 2007, 30, 147-171. [CrossRef]

10. Cox, M.; Ross, J. Robustness and vulnerability of community irrigation systems: The case of the Taos valley acequias. J. Environ. Econ. Manag. 2011, 61, 254-266. [CrossRef]

11. Allen, R.; Willardson, L.; Frederiksen, H. Water Use Definitions and Their Use for Assessing the Impacts of Water Conservation. In Proceedings of the ICID Workshop: Sustainable Irrigation in Areas of Water Scarcity and Drought, Oxford, UK, 11-12 September 1997.

12. Ochoa, C.; Fernald, A.; Guldan, S.; Shukla, M. Water Movement through a Shallow Vadose Zone: A Field Irrigation Experiment. Vadose Zone J. 2009, 8, 414-425. [CrossRef]

13. Bouwer, H. Artificial recharge of groundwater: Hydrogeology and engineering. Hydrogeol. J. 2002, 10, 121-142. [CrossRef]

14. Funk, P.; Walker, S.; Herbon, R. A systems approach to chile harvest mechanization. Int. J. Veg. Sci. 2001, 17, 296-309. [CrossRef]

15. Votava, E.; Baral, J.; Bosland, P. Genetic diversity of chile (Capsicum annuum var. annuum L.) landraces from northern New Mexico, Colorado, and Mexico. Econ. Bot. 2005, 59, 8-17. [CrossRef]

16. Walker, S.; Havlik, C. The Landrace Chiles of Northern New Mexico; Circular 679; Cooperative Extension Service, NM State University: Las Cruces, NM, USA, 2016.

17. Zeven, A. Landraces: A review of definitions and classifications. Euphytica 1998, 104, 127-139. [CrossRef]

18. Bosland, P.; Votava, E. Peppers: Vegetable and Spice Capsicums, 2nd ed.; Crop Production Science in Horticulture Series No.22; CABI: Wallingford, UK, 2012; ISBN 978-1845938253.

19. Walker, S. Red Chile and Paprika Production in New Mexico; New Mexico State University Research Guide H-273; New Mexico State University: Las Cruces, NM, USA, 2009.

20. Coon, D.; Votava, E.; Bosland, P. The Chile Cultivars of New Mexico State University Released from 1913 to 2008; New Mexico State University Research Report RR-763; New Mexico State University: Las Cruces, NM, USA, 2008.

21. United States Department of Agriculture Natural Resources Conservation Service (USDA-NRCS). 2011. Available online: http:/ / websoilsurvey.nrcs.usda.gov/app/HomePage.htm (accessed on 26 December 2011).

22. National Agriculture Statistics Service. Rio Arriba County, New Mexico 2007 Census of Agriculture. Available online: http://www.agcensus.usda.gov/Publications/200seven/Online_Highlights/County_ Profiles/New_Mexico/cp35039.pdf (accessed on 23 August 2017).

23. Natural Resources Conservation Services. Weather Station Data: \#2172. Available online: https://weather. nmsu.edu/wx-stn-data/network/scan/station/2172/request/data/ (accessed on 11 October 2017). 
24. Bosland, P.; Walker, S. Growing Chiles in New Mexico; Cooperative Extension Guide H-230; New Mexico State University: Las Cruces, NM, USA, 2004.

25. American Spice and Trade Association (ASTA). ASTA Analytical Methods. Extractable Color in Capsicums and Their Oleoresins; ASTA: Washington, DC, USA, 1987.

26. Collins, M.; Wasmund, L.; Bosland, P. Improved method for quantifying capsiacinoids in Capsicum using high-performance liquid chromatography. HortScience 1995, 30, 137-139.

27. Enciso, J.; Peries, X. Using flexible pipe (poly-pipe) with surface irrigation. In Irrigation Training Program; Publication Number L-5469; Texas A\&M AgriLife Extension: College Station, TX, USA, 2005.

28. Hargreaves, G.; Samani, Z. Estimating of potential evapotranspiration. J. Irrig. Drain. 1982, 108, $223-230$.

29. Matta, F.; Cotter, D. Chile Production in North-Central New Mexico; Cooperative Extension Guide; New Mexico State University: Las Cruces, NM, USA, 1993; pp. 1-3.

30. Samani, Z.; Herrera, E. A Low-Cost Water Measuring Device; Guide M-226; New Mexico State University: Las Cruces, NM, USA, 1997.

31. SAS Institute Inc. SAS/STAT Software: Changes and Enhancements through Release 9.3; SAS Institute Inc.: Cary, NC, USA, 2012.

32. Diaz-Perez, J.; Granberry, D.; Seebold, K.; Giddings, D.; Bertrand, D. Irrigation levels effect plant growth and fruit yield of drip-irrigated bell pepper. HortScience 2004, 39, 748.

33. Steduto, P.; Hsiao, T.; Fereres, E.; Raes, D. FAO Irrigation and Drainage Paper 66. Crop Yield Response to Water; Food and Agriculture Organization of the United Nations: Rome, Italy, 2012. Available online: http:/ / www.fao.org/docrep/016/i2800e/i2800e.pdf (accessed on 18 September 2017).

34. Harvell, K.; Bosland, P. The environment produces a significant effect on pungency of chiles. HortScience 1997, 32, 1292.

35. Wierenga, P.; Hendrickx, J. Yield and quality of trickle-irrigated chile peppers. Agric. Water Manag. 1985, 9 , 339-356. [CrossRef]

(C) 2018 by the authors. Licensee MDPI, Basel, Switzerland. This article is an open access article distributed under the terms and conditions of the Creative Commons Attribution (CC BY) license (http:/ / creativecommons.org/licenses/by/4.0/). 